\title{
Groundwater Management in Ukraine and the EU
}

\author{
By Viktor Ladychenko ${ }^{1}$, Olena Yara ${ }^{2}$, Liudmyla Golovko ${ }^{3}$, Viktoriia Serediuk ${ }^{4}$
}

\begin{abstract}
The purpose of our scholarly work is to explore legal regulation of sustainable use and protection of groundwater resources in Ukraine and the EU. Our study is organized around the following main issues: groundwater management, legal regulation of monitoring of groundwater resources, protection of groundwater from nitrate contamination. In this paper we review the current situation in groundwater policy in Ukraine, discuss the problems related to this situation and present recommendations for their solution. Based on comparison analysis differences and common problems of protection of groundwater resources in Ukraine and EU member states were determined. Ways of improving the mechanism of groundwater monitoring in Ukraine were proposed. Prevention of water pollution due to runoff of nitrates from agricultural lands was considered.
\end{abstract}

Keywords: EU water policy, groundwater, water legislation, water management, water quality

\section{State of Groundwater in Ukraine: Challenges for the Future}

In Ukraine significant population density, concentration of industrial and agricultural industries that require a large amount of water had a serious impact on the environment, including groundwater, 10-15 times larger than in neighboring countries. In the conditions of limited and uneven distribution of water resources on the territory there is a problem of sustainable water supply with minimal ecological and economic losses. Due to the intensive exploitation of underground waters, depression craters were formed in the Seversky Donets valley, Kiev, Melitopol, Poltava and Kharkov (a decrease in the level of groundwater in Kiev - 70 m, Poltava - 80 m, Kharkov - $100 \mathrm{~m}$ ). Under the influence of mining works, aquifers are drained in the southwestern part of Zaporozhye region, Krivbass and Nikopol manganese ore basin. Mine waters of high salinity drain into lower aquifers and migrate over long distances, salting the fertile soils and surface fresh waters of the south of Ukraine (Quality and ecological status of groundwater, 2017).

\footnotetext{
${ }^{1}$ Doctor of Law, professor, head of the Department of International Law and Comparative Law of the National University of Life and Environmental Sciences of Ukraine

${ }^{2} \mathrm{PhD}$, professor of the Department of Administrative and Financial Law of the National University of Life and Environmental Sciences of Ukraine, Dean of the Faculty of Law of the National University of Life and Environmental Sciences of Ukraine

${ }^{3} \mathrm{PhD}$., associate professor of the Department of International Law and Comparative Law of the National University of Life and Environmental Sciences of Ukraine

${ }^{4} \mathrm{PhD}$., associate professor of the Department of Theory of Law and State of the Taras Shevchenko National University of Kyiv
} 
Assessment of groundwater quality parameters at water intakes shows the tendency of deterioration in water quality. The reasons for the deterioration of the quality of groundwater are: the consequence of the violation of hydro-chemical regime, complex interaction of natural processes and a variety of man-made impacts on groundwater. Chemical pollution associated with industrial wastewater is a major threat to groundwater quality due to its high toxicity. The greatest harm to human health is caused by the following elements: mercury, manganese, copper, lead, zinc, chromium, etc.

The quality of groundwater is also deteriorating due to the receipt by groundwater horizons of contaminants from sewage and waste waters, and intensive exploitation of productive aquifers horizons mainly in areas where large industrial and agricultural facilities, etc. are located. In Ukraine more than 290 centers of groundwater pollution in major aquifers were identified and in more than 90 existing intakes a progressive deterioration of water quality has been observed.

Groundwater, which is the main source of water supply in rural areas do not always meet the requirements for drinking water, primarily due to increased content of nitrates, phosphorus, etc. Status of water supply to rural population is of a peculiar concern as the centralized water supply covers only 25 per cent of rural settlements of Ukraine (Gulak, 2016).

Pollution of water with nitrates causes various diseases, decrease of general resistance of organism and as a consequence, results in increase of level of general disease rate, in particular, to infectious and oncological diseases. Non-compliance of drinkable water with the regulative requirements is one of the reasons for dissemination of many infectious and non-infectious diseases.

Implementation of the EU water legislation is very important for Ukraine, not only because of the need to comply with the Association Agreement between Ukraine and the European Union, but also because of the urgent need for progressive reforms and the introduction of European standards in the country (Ladychenko, 2017). It can make the management of water resources in Ukraine more efficient and improve the quality of groundwater resources.

\section{Groundwater EU Legislative}

In the European Union several directives were adopted for protecting groundwater from pollution and deterioration: Directive 2000/60/EC of the European Parliament and of the Council establishing a framework for the Community action in the field of water policy (Water Framework Directive), Directive 2006/118/EC of the European Parliament and of the Council of 12 December 2006 on the protection of groundwater against pollution and deterioration (Groundwater Directive), Council Directive 91/676/EEC of 12 December 1991 concerning the protection of waters against pollution caused by nitrates from agricultural sources (Nitrates Directive), Council Directive 1999/31/EC of 26 April 1999 on the landfill of waste (Landfill Directive) and Directive 2008/105/EC of the European Parliament and of the Council of 16 December 2008 on environmental quality standards in the field of water policy. 
EU Water Framework Directive is the most significant legal instrument in the water field. Basic features of the Water Framework Directive are: focus on the result achieving a "good" state for all water objects; an integrated approach to the protection of all surface and groundwater bodies; water management by basin principle; multy-level monitoring; strengthening cross-border cooperation; large-scale involvement of citizens and stakeholders in development of water policy; improvement of water legislation.

Groundwater planning within the EU regulatory context derives directly from the components of the Water Framework Directive, covering the following steps: definition and characterization of groundwater bodies (management units) within well-defined river basin district; establishment of registers of protected areas within each river basin district, which have been designated as requiring specific protection of their surface and ground waters or for the conservation of habitats and species directly dependent on water; design and establishment of groundwater monitoring networks based on the results of characterization and risk assessment to provide a comprehensive overview of groundwater chemical and quantitative status; development of river basin management plan for each river basin district, including a summary of pressures and impacts of human activity on groundwater status, a presentation in map form of monitoring results, a summary of the economic analysis of water use, as well as the implementation of the principle of recovery of costs for water services, including environmental and resource costs in accordance with the polluter pays principle, a summary of protection programmes, and control and remediation measures (Jakeman, 2016).

The Groundwater Directive establishes quality criteria that take into account local characteristics and requires EU member states to establish the standards (threshold values) at the most appropriate level, taking into account local or regional conditions. Article 6 of the Groundwater Directive obliges EU countries to implement all measures necessary to prevent inputs of hazardous substances into groundwater and to identify those substances which are relevant.

Regarding the compliance of Ukrainian legislation with the EU environmental law in the sphere of groundwater protection, it can be concluded that, in general, Ukrainian national legislation has the same goal, subject and methods of legal regulation. Essential difference between EU and Ukrainian legislation is that Ukrainian normative legal acts are mostly declarative and are not fulfilled in practice. In order to bring Ukrainian legislation closer to the groundwater EU legislative, it seems advisable to: introduce measures to prevent or limit inputs of pollutants into groundwater; develop groundwater monitoring programs in order to evaluate the quality of groundwater, trends in its development and impacts of human activity on groundwater status; develop maps of threats and risks of groundwater pollution and multi-year integrated management plans for achieving good status of water quality; disclosure of the quantitative and qualitative status of groundwater; determination of zones vulnerable to accumulation of nitrates and development of action plans for their use.

\section{Monitoring of Water Resources in Ukraine and the EU}

Actuality of monitoring of water objects and water resources is caused by significant deterioration in the state of water resources in urban and rural settlements and 
in the adjacent territories. The most widely discussed causes of water quality deterioration are an increase in the scale of technogenic impacts of urban ecosystems on all components of the environment and through them on the state of surface and groundwater; increase of discharge of wastewater from commercial and industrial waste (intentionally or through spills) into surface waters, chemical contamination from treated sewage and release of waste and contaminants into surface runoff flowing to surface waters (Moss, 2008.); urban runoff and agricultural runoff, which may contain chemical fertilizers and pesticides (Yang, 2010).

As a consequence of this pollution the ecological state of the freshwater ecosystem may change (Koff, 2016). It is important to identify the processes that determine the ability of the ecosystem to stay within a desired state or how the slowly changing variables and abrupt impacts will determine the boundaries beyond which disturbances may push the system into another state (Scheffer, 2003).

In the Water Framework Directive a thorough description of the monitoring of groundwater resources that should be done is given. In contrast to the current System of monitoring of water resources in Ukraine, the Water Framework Directive applies the principle of multi-level monitoring which varies significantly by objectives (Yara, 2018). The main purpose of surveillance monitoring is to establish long-term changes in water objects. Operational monitoring shall be undertaken in order to: establish the status of those bodies identified as being at risk of failing to meet their environmental objectives, and assess any changes in the status of such bodies resulting from the programmes of measures. Operational monitoring is used for objects with ecological state which is different from the category "good" state. Investigative monitoring shall be carried out: where the reason for any exceedances are unknown; where surveillance monitoring indicates that the category "good" state are not likely to be achieved and operational monitoring has not already been established, in order to ascertain the causes of a water body or water bodies failing to achieve the environmental objectives; or to ascertain the magnitude and impacts of accidental pollution, and shall inform the establishment of a programme of measures for the achievement of the environmental objectives and specific measures necessary to remedy the effects of accidental pollution.

One of the main requirements of the Water Framework Directive is establishment of programmes for the monitoring of water status in order to establish a coherent and comprehensive overview of water status within each river basin district. For groundwaters such programmes shall cover monitoring of the chemical and quantitative status. According to Water Framework Directive monitoring programs must contain:

- monitoring of groundwater quantitative status (the monitoring network shall be designed so as to provide a reliable assessment of the quantitative status of all groundwater bodies or groups of bodies including assessment of the available groundwater resource. Member States shall provide a map or maps showing the groundwater monitoring network in the river basin management plan);

- monitoring groundwater chemical status (the monitoring network shall be designed so as to provide a coherent and comprehensive overview of groundwater chemical status within each river basin and to detect the presence of long-term anthropogenically induced upward trends in pollutants); 
- monitoring of protected areas of drinking water - for those underground water objects, from which an average of more than $100 \mathrm{~m} 3$ of water per day is taken for drinking water supply;

- preventive-restrictive monitoring, which is mandatory for potential point sources of groundwater pollution in order to prevent groundwater contamination.

Ukrainian Water Code does not prescribe how the process of monitoring should be carried out. Thus, Ukraine should improve legislative regulation of water monitoring on the grounds of the model of the European Union. At the same time the main problem of implementation of the principles of the Water Framework Directive in Ukraine is the need of transition to European principles of water management, which should involve not just changes to the legislation of Ukraine, but also require a change of methods of water management and monitoring of water quality.

In Ukraine the main problem in reforming the system of monitoring the state of water resources, including groundwater, is the residual principle of financing environmental monitoring works. Despite the fact that formally hydrogeological work has been proclaimed as one of the priority activities of the State Service of Geology and Mineral Resources of Ukraine, this "priority" is not backed up by real financial support for many years. In Ukraine the network of observation wells began to be formed in the 50's -60's of the XX century. In the early 90-ies there were more than 7000 observation wells. In 2002, as a result of constant funding cuts, the number of observation wells was "optimized", having decreased six-fold to 1,148 wells. Further reduction of financing in recent years has led to an even more significant reduction in the number of observation wells, reduction in measurements of water levels, almost complete termination of chemical quality analysis of groundwater. Many years of miserable funding have caused a number of other problems - the issue of the well status has not yet been resolved, which has led to numerous cases of their destruction. Well equipment, which is used, as a rule, is the same as 100 years ago, the water level is measured manually using roulettes (Shestopalov, 2016). As a result, it is almost impossible to make an informed forecast of groundwater quality development.

Since groundwater is an important source of drinking water supply, in Ukraine there is a need for a significant increase in the monitoring of aquifers and introduction of problem-oriented monitoring. In this regard microbiological monitoring of water quality in wells in rural areas and monitoring of the most perspective groundwater horizons are of great importance.

Another problem area is detioration of quality of groundwater as a result of the impact of solid domestic waste due to a large number of landfills and burial sites for domestic waste. In Ukraine specific indicators of waste are on average 220-250 kg per year per person, and in large cities reach 330-380 kilograms per year respectively. Solid domestic waste is mainly buried at 4,157 landfills with a total area of about 7.4 thousand hectares and only about 3.5 percent of solid household waste is burned at two incineration plants in the cities of Kiev and Dnepropetrovsk. It is estimated that about 0.1 percent of household waste is hazardous (Analytical note, 2017). Unfortunately, such a disappointing picture of household waste management in Ukraine has no tendency to improve. That is why it is necessary to improve monitoring of landfills of domestic and 
industrial wastes, abandoned reservoirs and other local pollution sources and their impact on groundwater.

Ukraine currently requires the assessment of the real state of surface and groundwater; determining the list of immediate and urgent environmental measures aimed at reducing water pollution, improving their ecological state, ensuring sustainable water use.

\section{Protection of Water against Pollution Caused by Nitrates from Agricultural Sources}

Nitrate contamination of water sources, eutrophication and related threats today are relevant to society. For river waters of Ukraine very high level of pollution with mineral forms of nitrogen is distinctive. General viewing during the last 10 years showed decreasing of levels of nitrogen pollution but it is still quite high (Riabec, 2011). Increasing of mineral nitrogen in the Azov sea area is observed. There is some increasing in contents of pesticide pollution in the Black Sea for chlorine-organic compounds (Ministry of Ecology and Natural Resources of Ukraine, 2015).

Currently provisions of the Directive $91 / 676 /$ EEC concerning the protection of waters against pollution caused by nitrates from agricultural sources (the Nitrates Directive) are not implemented in the national legislation of Ukraine. According to the Law of Ukraine "On the Fundamentals (Strategy) of the State Environmental Policy of Ukraine until 2020 " of 21 December 2010 № 2818-VI issues related to prevention of water pollution due to runoff of nitrates from agricultural lands is one of the priority areas of harmonization of Ukrainian environmental legislation with the provisions of EU law. At the same time, it should be noted that implementation of the Directive should not be perceived only as a technical task (just as adoption of specific legislative norms). The main tasks in the sphere of implementation of the Nitrates Directive are as follows: adoption of national legislation and determination of the authorized body (bodies); determination of zones vulnerable to accumulation of nitrates; introduction of action plans for zones vulnerable to accumulation of nitrates; introduction of monitoring programs.

The challenges of the implementation of the Nitrates Directive should also be assessed. Compliance with European environmental requirements in the field of storage and use of organic fertilizers will be problematic for agricultural producers because of their relatively low level of environmental awareness and limited own funds to finance the necessary measures. The Nitrates directive in Ukraine concerns 3,500 agricultural enterprises (half of them have farms with 100 to 1,000 head of cattle) and 1.3 million rural households (one third of them have 2-4 or more heads of large horned cattle). They must be equipped with special impermeable containers and storage areas for manure in the absence of own funds and limited sources of financial resources, because banks tend to refuse to provide loans to agricultural producers for these purposes. Therefore, it is necessary, in parallel with the implementation of the Nitrates Directive norms in national legislation, to create educational courses, a web resource, to intensify the counseling service in order to improve the level of thematic education of agricultural producers. It is advisable to provide them with budget support for the construction of organic fertilizer storage facilities, the purchase of vehicles and mechanisms for their proper placement in 
areas vulnerable to nitrate pollution. For example, in Latvia, these costs were financed from the state budget for approximately $50 \%$, and at the same time not all agricultural producers coped with the necessary work during the transitional period (Ecological innovations..., 2016).

The European Union has formed an extensive network of monitoring of groundwater pollution caused by nitrates from agricultural sources, which gave the possibility to identify the source of getting nitrogen compounds and choose the methods of its localization. Ukraine should use this experience, especially concerning emissions of nitrogen compounds. At the same time fragmentation of land use complicates the process of monitoring of contamination of water objects from agricultural sources.

According to V. Holian, O. Sakal and N. Tretiak, with whom we should agree, at the regional level there should be established a working group with representatives of the Department of agricultural development of regional administrations, NGOs, regional units of the State science and technology center for protection of soil fertility, State service of Ukraine for geodesy, cartography and cadaster, State water resources agency of Ukraine with the goal to develop a roadmap for the implementation of Directive 91/676/EEC. This is necessary because due to the significant number of households engaged in agricultural production and their fragmentation many problems concerning development of measures for formation of system for monitoring of discharges of nitrogen compounds into the water will arise (Holian, 2015).

Implementing the Nitrate Directive EU member states have drawn up action programs: there are more than 300 of them across the whole EU. The quality of programs is improving. Farmers are becoming increasingly positive about environmental protection, exploring new techniques such as manure processing (Funta, 2014). Taking into account high level of domestic pollution of surface and groundwater with chemicals and nitrates through the use of fertilizers on steep slopes and near water bodies implementation of European experience is a necessary condition for sustainable land use and preservation of quality of water resources.

\section{Conclusions}

In EU member states has been considerable advance in the identification and characterisation of the state of groundwater bodies, driven by the demands of the Water Framework Directive. EU member states generally have a comprehensive overview of their groundwater resources in their countries. However, in some regions there are insufficient data about the current state and trends of development of groundwater conditions.

Protection of groundwater depends on a good quality of knowledge about groundwater in the region, including its current status and pressures on it. To further improve groundwater management in EU member states, the following topics need to be addressed by basic and applied research: a thorough groundwater survey in Europe for water policy development and evaluation; improvement of environmental information disclosure; addressing rapid growth in unlicensed pumping; determination of the efficiency of measures against different pressures; prevention of groundwater pollution by nitrates. 
The analysis of the practical results of groundwater quality assessment demonstrate the ineffectiveness of Ukrainian working system of the groundwater protection regulation. It is necessary to improve, based on the experience of EU member states, the relevant environmental regulatory framework, significantly increase the volume and effectiveness of environmental protection measures that reduce and neutralize the negative mancaused impact on groundwater, strengthen control and penalties for businesses, farms and individuals violating environmental legislation. Implementation of the European standards for groundwater monitoring in Ukraine requires significant organizational and material expenditure to obtain initial information on the status of the groundwater bodies.

To improve groundwater quality evaluation system its methodology should be changed. It is also should be underlined that for reliable assessment of groundwater quality in Ukraine the usage of EU member states' monitoring programs as models for developing of national monitoring programs are of high importance.

In Ukraine it is necessary: to start the implementation of measures that would allow to assess the current state of the groundwater observation wells network; improve legal regulation of groundwater monitoring, to implement a number of organizational measures for coordinating the activities of the monitoring entities and ensuring more efficient use of information concerning the status of groundwater. It is evident that the need for a new, more realistic and qualitative assessment of groundwater resources using modern methodological approaches and computer technology is obvious. It is necessary to perform a survey and evaluation of the main explored but not exploited groundwater deposits in order to confirm or refine groundwater reserves, especially in terms of correctness of the assessment of chemical composition of groundwater, conservation of sanitary zones, etc. In this regard, it is necessary to more concretely and more fully identify and evaluate human pressure on groundwater resources.

The integration of water management policies into other policies dealing with human activities is an absolute necessity. There is the need to improve the standards for the construction and conservation of wells.

\section{References}

Analytical note on water and health issues of Ministry of Ecology and Natural Resources of Ukraine (2017). Retrieved from: https://menr.gov.ua/news/31881.html

Ecological innovations of the implementation of the Common Agricultural Policy in Ukraine: a scientific and analytical note (2016). Kyiv: Institute of Economics and Forecasting of NASU.

Funta, R., Nebeský, Š., Juriš, F. (2014). Právo európskej únie. Brno: Tribun EU.

Gulak, O. (2016). On the issue of legal regulation of environmental safety in Ukraine. International Scientific Journal, 2, 145-148.

Holian, V., Sakal, N., Tretyak, N. (2015). Regulation of activity of households in the context of protection of waters from pollution by nitrates from agricultural sources: Ukrainian realities and the possibility of implementing European experience. Agrosvit, 20, 6-16.

Jakeman, A.J., Barreteau, O., Hunt, J.R. (2016). Integrated groundwater management: cocepts, approaches and challenges. Springer imprint: Wisconsin.

Ladychenko, V., Golovko, L. (2017). Implementation of European Environmental Policy in Ukraine: Problems and Prospects. European Journal of Sustainable Development, Volume 6, № 3, 333-339.

Ministry of Ecology and Natural Resources of Ukraine (2015). Retrieved from: https://menr.gov.ua/news/31768.html 
Moss, B. (2008). Water pollution by agriculture. Philosophical Transactions of the Royal Society of London. Series B, Biological Sciences, 363, 659-666.

Quality and ecological status of groundwater (2017). Retrieved from: http://www.novaecologia.org/voecos261-1.html

Riabec, K. (2011). On the Issue of Organizational and Legal Support of Water Quality. Legal Science, 6, 84-89.

Scheffer, M., Carpenter, S.R. (2003). Catastrophic regime shifts in ecosystems: linking theory to observation. Trends in Ecology and Evolution, 18, 648-656.

Shestopalov, V., Lyuta, N. (2016). State and ways of reforming the state system of groundwater monitoring, taking into account international experience and the requirements of the EU Water Framework Directive. Mineral resources of Ukraine, 2, 3-7.

Koff, T., Vandel, E., Marzecová, A., Avi, E., Mikomägi, A. (2016). Assessment of the effect of anthropogenic pollution on the ecology of small shallow lakes using the palaeolimnological approach. Estonian Journal of Earth Sciences, 65 (4), 221-233.

Yang, Y.-H., Zhou, F., Guo, H.-C., Sheng, H., Liu, H., Dao, X., He, C.-J. (2010). Analysis of spatial and temporal water pollution patterns in Lake Dianchi using multivariate statistical methods. Environmental Monitoring and Assessment, 170, 407-416.

Yara, O., Uliutina, O., Golovko, L., Andrushchenko, L. (2018). The EU Water Framework Directive: Challenges and Prospects for Implementation in Ukraine. European Journal of Sustainable development, Volume 7, № 2, 175-182. 